\title{
Toward a Technological and Methodological Shift in Music Learning in Spain: Students' Perception of Their Initial Teacher Training
}

\author{
Rosa M. Serrano' ${ }^{\text {ID }}$ and Oscar Casanova'
}

\begin{abstract}
Current education requires the integration of digital technology. It is necessary to analyze the impact of the use of this technology on the educational process, and how they can be adequately integrated. This study, carried out over seven academic years in a Spanish University, gathers the perceptions of 9l education students who were training to become schoolteachers: based on their own previous experience as students, and after having participated in a technologicalmethodological project. By applying qualitative methodology, we conclude that the effective integration of technology in the teaching process requires continual feedback between technology, curricular content, and pedagogy. To achieve this, university-trained schoolteachers need to offer their students a sequenced technological-methodological empowerment process. It is necessary to implement a technological and methodological modification of the teaching-learning process in the first years of university training, with the aim of achieving long-term repercussions on all educational levels.
\end{abstract}

\section{Keywords}

music education, digital technology, student perception, teacher education, successful educational actions

\section{Introduction}

In the most recent decades, people have been subjected to implacable technological advances with major repercussions on professional life, private personal circumstances, and society at large. Technological immersion has exerted a considerable impact on people of all ages, genders, and social conditions. It is common to see children on a bus playing with a smartphone, or nursery-age children immersed in a tablet while their family is eating at a restaurant. In 2009, Bringué and Sábada already found that young Spaniards had electronic devices and used them regularly. Currently, in Spain, according to the National Institute of Statistics (2020), $93.2 \%$ of the population aged 16 to 74 years have used the Internet in the last 3 months; more than $82 \%$ use it daily; and more than half have shopped on the Internet in the last 3 months. The term digital technology is a broad concept that includes technology for storage, retrieval, processing, and communication of information, including any sort of communication device such as radio, television, smartphones, video games, tablets, and computers, as well as the required hardware and software (Bautista, 2004).

The digital revolution which has taken place in general society exerts a pivotal influence on the specific domain of music. Digital technology provides an impressive quantity and variety of musical resources, and thus tend to be used particularly frequently in this area. The studies carried out by Bringué and Sádaba (2009) revealed that using digital resources to listen to music is the free-time activity most often chosen by girls, and the second-most common option chosen by boys apart from games. Music and technology are thus considerably intertwined, and are practically omnipresent in the daily life of children and adolescents.

\section{Digital Technology and Education}

This general technological revolution is taking place in the educational field as well. As we have observed, teachers, administrations, institutions, and educational legislation are openly opting in favor of integrating technologies into the teaching-learning process, evolving from featuring them as mere technical tools to ultimately using them as integral

'University of Zaragoza, Zaragoza, Spain

Corresponding Author:

Rosa M. Serrano, Department of Musical, Plastic and Corporal Expression, Faculty of Education, University of Zaragoza, Pedro Cerbuna, 12, Zaragoza 50009, Spain.

Email: rmserran@unizar.es 
teaching material (Colás et al., 2018; Coll et al., 2008; Prendes et al., 2018; Tapia Cortes, 2020). Studies carried out in the European Community on the benefits of digital technology in schools show that their use between the ages of seven and 16 can lead to significant learning improvement, particularly in areas such as English, the natural sciences, and Design and Technology (Balanskat et al., 2006). Students, teachers and parents all consider that these resources have a positive impact on learning in school because they improve the social pedagogy and learning experience between teachers and students and bring a democratization of learning and teaching (Tomczyk \& Oyelere, 2019). This is why some teachers are endeavoring to feature them in their practical teaching activities; certainly not all teachers do so, however, neither are the desired results always obtained (Tapia Cortes, 2020). Apart from such teaching efforts on an individual level, public administration institutions have been encouraging teachers for several decades to incorporate digital technology into their daily teaching activities, even providing financing for technological equipment, and for teacher training in certain cases (Dorfman, 2013, 2015, 2016). Despite the notable increase in infrastructures, digital equipment, and teacher training that drive technological implementation in educational institutions (Gómez, 2016), optimal results have not yet been achieved (Guerrero, 2014). Much still needs to be achieved, nevertheless, especially in terms of infrastructure and training - two areas in which clear deficiencies are still notable (Bauer, 2013, 2014; Rodríguez Correa, 2018). Skills and specific technologies that are eminently of the 21 st century, designed to favor information, communication, the sharing of ideas, critical thinking, creativity, and problem-solving (van Laar et al., 2017, 2020), seem not to have been systematically integrated into Spanish national study plans and classroom activities (van de Oudeweetering \& Voogt, 2018).

In the area of teacher training, it is necessary to introduce systematic planning to ensure that current students training to become preschool, primary, and secondary school teachers as well as university professors are all adequately formed to face these challenges (Román Álvarez, 2017). University professors should serve as models to promote a critical, creative selection of adequate digital resources for the classroom (Gall, 2017a; Martinovic \& Zhang, 2012; Taimalu \& Luik, 2019; Uerz et al., 2018). In addition, students benefit from the peer-to-peer networked learning that technology provides (Sloep \& Berlanga, 2011). Thus, technology need to be deliberately integrated into study plans for the first years of university teacher training (Martinovic \& Zhang, 2012). It is indispensable that future teachers receive adequate instrumental and pedagogical training in this sense, so that they may learn to apply effective models that can be easily reproduced in the classroom environment and can help them succeed in their tasks as teachers (Rodríguez Pérez, 2015). Students in university education departments require additional training in the area of digital skills in order for them to be able to adequately carry out their future tasks as professional educators (Gallego Arrufat et al., 2010), especially in view of the fact that the concept of the "digital native"-someone who purportedly knows how to implement technologies for effective and efficient acquisition of learning and construction of knowledge - does not correspond with reality (Bourke \& State, 2019; Kirschner \& De Bruyckere, 2017). We cannot think that as digital natives fill our classrooms, they will trigger the necessary change in teaching strategies and that only the passing of time will solve our educational problems (Adell, 2015). It is urgent to enhance teacher training not only in technical-instrumental but also in pedagogical competencies (Aróstegui, 2010; Serrano, 2017; Cózar Gutiérrez et al., 2015; Guerrero, 2014) that lead teachers to carry out good educational practices.

The objective of including digital technology in teaching is not only to digitally alphabetize students (e.g., to enable them to locate, analyze, organize, understand, and evaluate information via the use of digital technology); it also enriches the education process per se since they improve upon already existing didactic resources and potential, both in terms of teaching and of learning (Bauer, 2013; Canales \& Marquès, 2007). It improves classroom dynamics by enabling learning to take place at any time and place, and also by simplifying the evaluation process. For such inclusion of technology in the educational sphere to be effective, it is necessary to adequately foresee long-term goals, thereby adjusting curricular content and correctly selecting the methodology one wants to apply, in order to take maximum advantage of the numerous advantages offered by digital resources as compared to traditional resources such as books, the overhead projector, etc.

It is necessary to readjust and reformulate teaching methods, media, utilized materials and technologies, the role and functions of teachers in the classroom, study contents, activities and skills for development by students according to the new sociocultural and technological context in which the educational activity takes place. (Area, 2019, p. 371)

In order to obtain real improvements, teachers must take into account three main components: content, pedagogy, and technology; using "Technological Pedagogical Content Knowledge (TPACK model)" proposed by Mishra and Koehler (2006) as a framework for thinking (Gall, 2017b).

\section{Digital Technology and Musical Education}

In the specific area of music education, music technologies can help us generate, improve, and gain a better understanding of the art of organizing sounds to express feelings (Webster, 2002). A wide assortment of musical content can be better worked if they are supported by technology (Aróstegui, 2005; De Castro, 2015). Its use can favor, among others, multimodal processing, the stimulation of student 
autonomy and self-regulation, the creation of a positive learning climate and the enhancement of socio-affective and motivational aspects (Pritchard \& Woollard, 2010). The most worked aspects in compulsory music education are encouraging the monitoring of the subject and the active participation of students in the subject, especially in instrumental learning, enhancing the overcoming of learning difficulties of each one (Serrano, 2017).

Their use in the classroom, however, should not prevent teachers and students from carrying out a real musical performance: for example, singing, movement, or instrumental interpretation. Music learning can be enriched and enhanced by certain digital resources such as karaoke, video dances, accompaniment tracks, or similar interactive musical software (Giráldez, 2010; Juvonen \& Ruismäki, 2009); further learning experiences such as listening or creating one's own music can likewise be optimized when students use technology to develop their own composition projects. The creative, communicative and cooperative work between students has yet to be fully exploited (Serrano, 2017).

Many digital resources can be incorporated into music education: either general devices (computers, tablets, smartphones, and digital blackboards) or specific applications (concrete musical programs and apps such as music editing software, sequencers, sound editors, and digital simulators of acoustical instruments). Internet websites provide a significant quantity of material for music teaching and learning in the classroom as well as at home, thereby encouraging a student's autonomous musical development (Juvonen \& Ruismäki, 2009; Román Álvarez, 2017).

Technology likewise enables us to blend formal and informal learning (Green, 2016) by combining a series of variables such as music performance with others that adopt a playful approach to music, such as karaoke machines that correct a singer's intonation (Kallio et al., 2007). It is fascinating to work with such audiovisual resources, since they enable students to gain a better grasp of the language of music (Aróstegui, 2010; Montoya, 2013). Music education allows students to develop their own musical criteria and preferences rather than being influenced by music styles that are merely en vogue.

\section{Successful Educational Actions and Digital Technology}

In spite of the great quantity and diversity of available musical technology, the mere act of featuring it in the classroom does not mean that it is being adequately applied - in other words, this does not necessarily make it a Successful Educational Action (SEA). We can define SEAs with digital technology as any action that leads to an improvement or an enrichment of the teaching-learning process, thereby bringing about an improvement in its results (De Pablos \& Jiménez, 2007; Sosa Díaz et al., 2010). Furthermore, the use of digital resources should go hand in hand with methodological adjustments and adequate didactical strategies that encourage optimal learning, that is, learning in which the human educational experience is regarded as more relevant than the strictly technological aspect (Area, 2007, 2019; Bauer, 2014). Such successful experiences should be accompanied by an evaluation of the tasks and of the teacher's own educational practice (Canales \& Marquès, 2007), in order to serve as benchmarks in other contexts (Epper \& Bates, 2004).

Schools cannot be confined within a bubble that separates them from surrounding social reality; instead, a school should be pervaded by its social context. University education trainees need to be familiarized with any element that can help them beneficially exert their profession, that is, that can facilitate their work with school pupils. At the same time, they should resort to those elements and tools that are closest to them in their educational area (Domingo-Coscollola et al., 2020; Gudmundsdottir \& Hatlevik, 2018; Morales Capilla et al., 2015). Teaching and learning are inconceivable if we are not thoroughly immersed in the realities of the 21 st century (van Laar et al., 2020). This major societal shift, which has become necessary and is being demanded on a general level, can be extended to the area of music from childhood education to university. Technological progress and web innovation have revolutionized the music world; thus, they should likewise become an integral part of music education (Bauer, 2014; Giráldez, 2005).

Technologies "can enable us to improve the teachinglearning process and to enrich our musical experience in the classroom, while at the same time facilitating the teacher's organizational tasks" (Torres, 2011, p. 65). Musical technology enables teachers to conceive and design a great number of musical activities, and provides the possibility of communicating or sharing the resulting digital information with others (Casanova \& Serrano, 2016; Torres, 2011). Although the available panoply of technological tools can certainly help us produce a great variety of enriching learning situations, the conception of novel didactic activities and possibilities will ultimately depend on the teacher's imagination, his/her creativity and, most of all, his/her degree of digital training.

\section{Brief State of the Art}

In the most recent literature, several authors have investigated the benefits of using digital technology in the teaching and learning process, the incorporation of active and innovative methodologies with the support of technology, or the use of digital technology in initial teacher training.

Thus, Byrne and MacDonald (2002), through focus groups with teachers, confirmed the benefits that digital technologies bring to teaching and improved student learning. For their part, Calderón-Garrido et al. (2019) analyzed the scientific literature of the last 10 years and showed how, in general, digital technology has great benefits for both teachers and students. Sweeney et al. (2017), after reviewing technology-enhanced assessment, concluded that technology 
has long been used in conjunction with good assessment practices with the intention of improving student learning.

Vidulin-Orbanić and Duraković (2011) stated in the study conducted with 122 students that prospective teachers found digital technologies a way to optimize their time and reach students more directly compared to classical transmission of musical knowledge. Talsik (2015) conducted a series of online activities with prospective teachers; motivation toward learning was higher than in the case of face-to-face teaching. For his part, Pike (2017) analyzed attitudes in an online environment; his conclusions showed a rapid adaptation to this modality.

With a sample of 146 future teachers, Chen et al. (2017) demonstrated the effectiveness of the proposed methodology for the training of technological competencies; the process was based on the simultaneous training of media literacy and information culture. Alt (2018), with data from 303 teachers, concluded that training teachers in digital technologies increased their tendency to use them in the classroom. Taimalu and Luik (2019) considered that, in addition to knowledge, beliefs also influence technology integration.

Alonso-Ferreiro (2018) highlighted the importance of active methodologies in initial teacher training; likewise, with the implementation of a didactic project that integrated tasks with digital technologies, he noted the contribution to the development of the didactic component of digital teaching competence.

Ping et al. (2018) conducted a systematic review of the literature on teacher educators' professional learning; they highlight that teacher educators undertake different activities from which to learn. Meanwhile, in the review conducted by Uerz et al. (2018), on the competencies of teacher educators to foster prospective teachers' competence in teaching and learning with technology, four competencies were identified to fulfill their task of fostering student teachers' competence in teaching and learning with technology; competencies of teacher educators as role models. Sefo et al. (2017), after analyzing the use of digital technologies in the daily practices of both teachers and students, concluded that, for the most part, teachers are urged to have more practical than theoretical training.

The study on initial teacher training by Enochsson and Rizza (2009) shows that digital technologies are not used regularly or systematically in the 11 OECD countries analyzed. From a comparative perspective focusing on Germany, Spain, Finland, France, and the United Kingdom, Gabarda Méndez (2015) states that the results obtained on the integration of digital technologies are disparate and that, currently, more equipment or more technological training are not always synonymous of greater use of technologies. Results obtained by Instefjord and Munthe (2016) in Norway indicated that the use of technology does not feature prominently in curriculum documents; it suggests that digital competence is not yet considered an important component of teachers' professional competence.
The study by Losada et al. (2012), in which the curricula of 41 Spanish public universities were analyzed, showed that educational technology has not experienced an improvement in relation to its presence in the curricula of education degrees; these curricula do not guarantee specific training in educational technology to all their students. Prendes et al. (2018) examined the current situation of universities in Spain and their technological endowment to, subsequently, analyze the situation of university faculty. These authors conclude that universities must establish control mechanisms that guarantee the best training for students and ensure the acquisition of competencies, including digital competencies. Rodríguez Correa (2018) indicated that the role of university leaders for the incorporation of digital technologies in their centers would not be easy to exercise since they face significant changes at the scientific, economic and technological levels that largely determine the success of this integration. For their part, Calderón-Garrido et al. (2020), in their study with music education teachers in Spanish universities, found a superficial knowledge of the technologies, limited use in the preparation of classes, minimal use in class and almost non-existent teaching.

In view of all that has been indicated so far, focusing on the considerations of Spanish students, it can be affirmed that the work presented here attempts to contribute to knowledge on the subject under study. This longitudinal research has not been carried out in Spain so far.

\section{Objectives of this Study}

In view of all the above, we find it necessary to analyze the impact of the use of digital technology on musical teachinglearning processes. Such analyses need to be carried out on all educational levels; a study of their repercussions on applied teaching methodologies can incorporate them into the realization of SEAs.

Within the specific context of Spain, the aim of this study was to gather and analyze the opinions and perceptions of education trainees studying at university to become primary and secondary schoolteachers regarding the manner in which they experience the incorporation of technology in their general as well as their specifically musical educational experience, along with characteristics that can play a role in proposed SEAs. To achieve this, we asked participants to reflect upon their previous experiences in primary school, secondary school, and university. To pursue that general aim, we adopted the following specific objectives:

1. To analyze how students experience digital technology on different educational levels, both within a general educational context as well as in the specific domain of music education.

2. To ascertain which characteristics of experiences with technology in the educational area have been viewed as positive by the students. 
Table I. Sample Distribution. Total of Students Participating in the Project.

\begin{tabular}{lcccccrrr}
\hline & $2012 / 13$ & $2013 / 14$ & $2014 / 15$ & $2015 / 16$ & $2016 / 17$ & $2017 / 18$ & $2018 / 19$ & Total \\
\hline Grado & 46 & 46 & 39 & 66 & 65 & 150 & 123 & 535 \\
Master & 12 & 12 & 10 & 14 & 11 & 11 & 16 & 86 \\
Total & 58 & 58 & 49 & 80 & 76 & 161 & 139 & 621 \\
\hline
\end{tabular}

Table 2. Sample Distribution. Students Interviewed in Focus Groups.

\begin{tabular}{lcccccrrr}
\hline Focus group & $2012 / 13$ & $2013 / 14$ & $2014 / 15$ & $2015 / 16$ & $2016 / 17$ & $2017 / 18$ & $2018 / 19$ & Total \\
\hline Grado (FG-G) & 8 & 8 & 8 & 8 & 8 & 8 & 8 \\
Master (FG-M) & 5 & 5 & 5 & 5 & 5 & 5 & 5 \\
Total & 13 & 13 & 13 & 13 & 13 & 13 & 13 & 91 \\
\hline
\end{tabular}

3. To identify the hitherto applied type of methodology in educational practices that incorporate digital technology, and to analyze those projects which the students regard as Successful Educational Actions (SEAs).

\section{Method}

\section{Participants}

This study was carried out over a period of seven academic years, from 2012/2013 to 2018/2019. Our participants were a total of 91 subjects studying at the Education Faculty of Zaragoza University, forming part of a total of 621 students who participated in a long-term technological-methodological project over the course of those years. Among the 91 subjects, 56 (out of a large sample total of 535) were studying toward the degree of Grado en Magisterio in the specialty of childhood and primary education ( 31 female and 25 male), and 35 (out of a large sample total of 86) were studying toward a Master's Degree in Secondary and Artistic Education (19 female and 16 male). The median age was 23 (Grado students: 21.4 years old, and Master's students 24.5 years old). Data were transversally collected in the course of those seven academic years. The selected participants were chosen among all those who had voluntarily participated in the study, taking maximum variation criteria into account (Miles et al., 2013), such as differences in gender, age, initial training, previous teaching experience, and qualification for the assignment; each year we selected the same number of participants. The sample distribution is presented in Tables 1 and 2.

The students in the sample of participants selected for this study were all enrolled in the obligatory "Music Didactics" course pertaining to their third academic year toward the obtention of a Grado en Magisterio in Childhood and Primary Education, or enrolled in the course entitled "Curricular Music Education Design" as part of the study curriculum toward a Master's Degree in Secondary Education (the course was offered in first semester of the sole academic year required to obtain a Master's after a Grado). Precisely during that period, a technological-methodological integration project imparted by this study's authors, fully recognized and encouraged by the University, was being implanted in those courses, with details as follows.

\section{The Technological-Methodological Integration Project}

The participants in this study were students who were actively involved in a technological-methodological integration project over the course of an academic year. The project's didactic aim was to introduce a series of technological resources and applications, all of which were designed to fulfill an educational function: general tools used in concrete musical situations, as well as musical tools specifically selected for one of the two above-indicated university music education courses. In order to adequately integrate those resources and applications, a corresponding methodological implementation was taken into account.

Concretely, we proposed an active methodology centered on the student, with a specific educational focus on flipped learning and gamification. Its design was carried out during the first month of the course and revised throughout its implementation. These approaches aimed to optimize learning, independent study, and collaboration among students between class sessions, in order to efficiently make the best use of each class session, in which practical, interactive tasks were featured prominently along with debate and critical reflection. In order to encourage the students' motivation and engagement in the subject matter, we added a system of challenges and rewards in activities that featured competition among individuals or groups. We applied a great variety of software applications: in the area of general education, they included programs designed for content curation, evaluation in categories, managing audiovisual activities, creating questionnaires, and gamifying activities. In the specific area of music education, we featured programs for sound editing, simulation of instruments, score editing, sequencing, and the generation of musical databases. 
Since these university students would soon be exerting their profession as schoolteachers, we found it important to propose an empowering process in three phases, implemented throughout the semester of each subject. The first phase was designed to help the students gather experience: the professor guided their choice of proposals, whereas the students decided when, where and to what degree the tools at their disposal were to be used in the period between class sessions. In the intermediate phase, "Guided Empowerment," the professor played the role of a mediator who took up the students' proposals and integrated them into the course's educational sequence. In the final phase, "Total Empowerment," the students became the protagonists of the educational process: they applied their own proposals in the classroom, while the professor retreated into the background role of a guiding observer. Thus, these students were able to experience the project's proposed technological-methodological integration from the perspective of a student and also in the role of a teacher.

\section{Study Design: Tools and Techniques for Data Collection and Analysis}

This study's objective was coupled with a qualitative methodology: our aim was to understand reality as it is apprehended by subjects within the context in which it is constructed (Denzin \& Lincoln, 2005; Flick, 2014, 2015; Gibbs, 2012; Strauss \& Corbin, 2002). Qualitative research seeks to "unpick how people construct the world around them, what they are doing or what is happening to them in terms that are meaningful and that offer rich insight" (Flick, 2015 , p. 13). One function of qualitative research is to find models and produce explanations: thus, our study tends to interpret results with the aim of arranging them in an explanatory schema. Qualitative research enables us to obtain important information about what goes on in certain realworld situations: such experiences can then be transferred to other contexts.

Basing ourselves on Kvale (2011) and Flick (2015), we arranged our study in seven sequential phases:

1. Formulating the study's objective and laying out its thematic organization

2. Planning the research design

3. Elaborating a semi-structured script for discussion in focus groups

4. Gathering data

5. Data analysis based on the study's objectives

6. Triangulating data: verifying it, establishing the findings' validity, reliability, and capacity for generalization

7. Communicating the study's findings

The tool we selected to gather the perception of our students was the semi-structured interview carried out in focus groups - one of the most widely used techniques in social and educational research, known to provide valuable data while pinpointing important areas and interesting subjects that can emerge in the course of discussion (Blaxter et al., 2008; Kvale, 2011; Smith \& Osborn, 2015; Smith et al., 2009).

Focus groups, according to Palmer et al. (2010), are a tool that can provide considerable enrichment, since they not only allow several different voices and opinions to be heard in the course of one session, but also because they provoke a greater deal of experiential reflection than could be achieved in a mere one-on-one individual interview. A group environment allows its members to "co-constitute narratives and multiperspective accounts that would probably not have emerged in single interviews" (p. 117).

To analyze the validity of the questions in our script, we consulted a team of professors specialized in the joint domain of education and technology. Our goal was to ascertain whether the script items provided a full and adequate reflection of our study's objective; it was also important to pinpoint certain elements which might eventually be redundant. Following that evaluation by the team of experts, we asked several students to review the questions in order to judge their degree of comprehensibility and appropriateness in terms of vocabulary, and in order to ensure that participants would interpret their meaning unequivocally. The 15 questions in the script corresponded with the following three dimensions: (a) experience, (b) learning, and (c) satisfaction and motivation.

The script contained precise questions; however, it was only used as a guide, thereby permitting a certain degree of flexibility in the course of group discussion. Before data collection we carried out a brief pilot test, after which certain minor adjustments were made to the original script.

In terms of number of participants per group, the focus groups of Grado students were composed of eight people, whereas the focus groups of Master's Degree students were of five people each (Table 2). We organized 14 discussion groups in total. We asked them to interact among themselves while focusing their recollection on positive and negative experiences associated with the use of technology in the classroom. Using a digital voice recorder, an audio recording of each discussion group session was made, which served as the basis for a subsequent word-for-word textual transcription. To avoid exerting undue influence on the participants' opinions, the focus groups were moderated by a researcher who did not form part of the technological-methodological integration project carried out in the musical assignment courses. The average duration of each discussion group was 90 minutes.

Ethical approval for this project was obtained from the University of Zaragoza in accordance with the requirements for this type of study. Participants were informed about the 
study's objective, and they signed a consent document. All participants were volunteers, and they were informed of their right to abandon the sessions at any moment they wished. We likewise requested their permission to make an audio recording of the group discussion while assuring them that their data would remain anonymous and confidential. Their personal identity was protected by omitting any detail that might have led to identification. The discussion sessions were carried out at the point in time when the students had finished and met all academic requirements associated with the musical assignment that formed part of the methodological-technological integration project.

The discussions were transcribed word-for-word and analyzed following the main analytical principles of the Interpretative Phenomenological Analysis (IPA) (Eatough \& Smith, 2017; Smith \& Osborn, 2015; Smith et al., 2009), to provide detailed examinations of personal lived experience in its own terms rather than one prescribed by pre-existing theoretical preconceptions and prior to the move to more general claims, with all pertinent adaptations to the specific situation of group discussions as opposed to individual personal interviews (Palmer et al., 2010; Tomkins \& Eatough, 2010). Our analytical procedure followed the steps detailed as follows (Eatough \& Smith, 2017; Moustakas, 1994; Palmer et al., 2010; Smith \& Osborn, 2015; Tomkins \& Eatough, 2010):

1. Read the transcription of the first interview several times and note interesting points of discussion.

2. Reread the transcription, now transforming the notes and initial ideas into more specific themes and phrases.

3. Further reduce the data by establishing connections between preliminary themes and grouping them together accordingly.

4. Select descriptive titles for general themes in order to grasp their conceptual nature.

5. Repeat Steps 1-4 for the transcriptions of all the other interviews.

6. Identify similarities and differences among the themes derived from the different interviews.

7. Organize themes and subthemes from the interviews into a diagram.

8. Select representative examples that capture the essence of each theme and subtheme. In our case we show the original texts of the participants, translated from Spanish.

Four categories/themes emerged from this analytical process: (1) experience with digital technology in a series of different contexts; (2) teacher characteristics; (3) methodology, and (4) characteristics of SEAs with technology. We go into further detail regarding these four categories in the Results section.

\section{Results}

\section{The Experience With Digital Technology in Different Contexts}

One of the aspects in which we were most interested during the 7 years of this study was to gather students' perceptions of their educational experience with technology in three differentiated stages. The first was the pre-university stage: we asked about the students' experiences in primary and secondary school, both in general education and in music education. The second one referred to university education apart from musical courses; the third one corresponded with the university music education training context of which the technological-methodological integration project formed part.

The data obtained show that technology had only been minimally integrated in the subjects' educational experience prior to university, with no differentiation among musical and non-musical school subjects.

The only digital experiences in primary and secondary school reported by the students were the videos they watched in class, or the information they were asked to collect online at home, as one of them remarks:

With my teachers in primary and secondary school, we never used digital resources in class, except when they had us watch audiovisual material or required that we search for information (Focus Group-Grade [FG-G], 2016/17).

In the second context-non-musical university training students indicated a greater degree of ICT use in class. Analysis reveals that in almost all cases such use was merely limited to a professor's PowerPoint presentations in class, or to uploading such presentations or notes to the Moodle platform.

A greater use of technology was observed in those specifically musical university courses in which the technologicalmethodological integration project was introduced. Specific tools were featured in such courses, and the students pointed out a series of positive aspects such as the choice of different resources in function of an assignment's aim and the resource's educational usefulness. This can be inferred from remarks such as the following:

This was the first time we used so many and such a variety of different digital resources; in educational terms, they have been really useful (Focus Group-Master [FG-M], 2017/18).

Digital technology should not be only regarded as sources of motivation, but also as a means of improving the teachinglearning process [. . .]. It is important to use each resource for the goal to which it most adequately applies (FG-M, 2016/17).

As these and similar remarks indicate, students appreciated the variety of technological resources that were integrated in university music courses and emphasized that they 
found such resources useful for improving the educational process in which they were involved. They likewise appreciated the importance of experiencing such technologies hands-on:

At first, I found it difficult to adapt myself to the technologies in this course because I was not used to them, but I have enjoyed the experience. What better way to apply such resources in the future than to experience their usefulness oneself, the opportunities they provide us, as well as their possible limitations (which we can attempt to overcome)! (FG-G, 2015/16).

A comparative analysis of results from all seven academic years reveals that the data scores tended to reoccur in the same proportions within the three educational stages, with similar results across all 7 years. This indicates that technological integration is not increasing. It is especially true of pre-university education and non-musical university courses, where the results regarding technological tools and their degree of use remained constant. This is a cause for concern, since it implies that education is neither keeping pace with transformations in society, nor with the increased general use of technology.

\section{Characteristics of the Teacher}

Our analysis revealed a great disparity among existing situations. The participants pointed out that such differences depend widely on the learning institution and on the teacher in whose class they were. When referring to institutions, they most often mentioned the presence or absence of digital resources, along with the school's quality of Internet service, and its priority policies. When referring to their teachers, the students provided a considerable quantity of information that is of great relevance to our aim as university professors, which is to train and form future schoolteachers. We therefore devote our second analysis unit to this important aspect.

The reality experienced by our subjects with respect to their teachers and the use of digital resources in the classroom was quite varied, and they were aware of this when they shared their experience with their colleagues, as the following remark shows:

Our teacher in that subject in school used them a lot, but that was just because it was "his thing": he liked technology and found that it was a good way of working with kids in class. He was convinced of their usefulness and spent a lot of time looking for apps and preparing interesting activities for his students. But talking with my fellow university students I have seen that this was not the usual case, and many of them never had an experience like the one I had with that teacher (FG-M, 2017/18).

When the students were asked to express which positive teacher traits encouraged the integration of technology into the school subject, they most frequently pointed out the teacher's previous experience and/or the teacher's persuasion that digital use would be beneficial, as expressed in the abovecited remark. They often remarked that their former schoolteachers did not possess enough know-how to apply technology optimally in their teaching; in fact, they were often technologically less proficient than their own students.

Among the pedagogical challenges mentioned by our participants, they pointed out the general need for ongoing training in order to always remain up to date, both in terms of technology and in terms of pedagogy. They were nevertheless also aware of the effort this involves, an effort not all teachers are willing to exert.

\section{Digital Methodologies}

Apart from gathering knowledge concerning the general application of technology in the classroom, one of this study's aims was to analyze the methodology with which such activities tend to be carried out.

In the area of experience prior to the university music courses - in general and specifically musical school education, as well as in non-musical university courses - the students found that the applied methodologies tended to be traditional, consisting in lecture classes, the use of books, and individual assignments. Results are similar among Grado and Master Degree students, and remain constant along the seven years over which data were collected. This shows the prevalent lack of progress in terms of pedagogical methodology, both in general and music education, as previously noted in the above-analyzed use of digital technology.

On general terms, students found that in their pre-university experience as well as in non-musical university courses, the use of technology was not associated with up-to-date methodology (such as flipped learning or collaborative learning on the Web); instead, the teachers' approaches only tended to reinforce traditional educational methodologies, exclusively based on lecture-style classes and individual study. They often mentioned non-musical university courses in which the professor would project PowerPoint-style slide presentations as a resource that reinforced the lecture aspect: the digital presentations were subsequently uploaded, along with the course curriculum, to the university faculty's digital platform.

Actually, nothing about the class changed: the professor explained the subject matter using PowerPoint presentations that he uploaded so that we could consult them in our study time (FG-G, 2018/19).

Students evaluate such approaches negatively; they demand more active methodologies such as those proposed in the university music courses, where the student assumes the role of a protagonist of his/her own learning, an experience that stimulates cognitive, creative, and collaborative development. This is reflected in a student's remark about flipped learning as applied in university music courses: 
This methodological approach has awakened a keener interest and motivation in me for these subjects. I have participated much more actively than in other courses. Being allowed to elaborate my own resources has led me to truly know and confidently make us of technology along with the active methodologies with which they are associated (FG-M, 2014/15).

Students are aware of the difficulty involved in learning to apply new didactical methodologies, approaches, and resources they have never previously encountered in their education. That is why practically all students positively valued their use in the role of student and teacher, while maintaining a critically reflective attitude toward them.

I recognize that it is sometimes complicated to leave behind those methodologies we have previously experienced; moreover, in this Master curriculum, these are methodologies with which I was generally not confronted in the course of my primary and secondary schooling. [ . . .] The fact of being able to experience them, use them, and reflect upon them has greatly contributed to the figure of teacher I want to embody in the future (FG-G, 2015/16).

In the future, the best way to apply these active, participative methodologies to students is, first of all, to experience their usefulness first-hand oneself, the opportunities they provided us, and their possible limitations (in order to resolve them) (FGM, 2017/18).

\section{Characteristics of Successful Education Actions With Digital Technology}

As previously explained, the subjects who participated in this study were students attending university music courses that applied a technological-methodological integration project. After the implementation of the project, they were asked to participate in the focus group. The students assessed their experience with this project as a SEA with digital resources: the assessments in each academic year were positive.

The students' comments regarding what permitted them to qualify the experience with technology as a SEA led them to select those digital resources in a project that were more adequate in function of its purported objectives, and not the inverse. Another aspect positively valued by the students was that the use of a variety of such technological tools tended to reinforce their own critical and reflective analysis of the possibilities at their disposal in an educational context. A sequenced programing of tasks works in favor of achieving a SEA.

In this course, we have used a great variety of different digital resources, depending on the task we had to carry out. Reflecting about this has made me aware of each tool's possibilities, and of how it is necessary to plan the task in order for the activity to turn out as intended (FG-G, 2013/14).

These activities included practical assignments with dynamic, collaborative activities in which the degree of student participation was remarkably high. Personalized work, collaborative teamwork and the incorporation of gamification elements in the digital dynamics all worked in favor of socio-affective and emotional aspects which, in turn, had positive repercussions on the learning process, thereby helping students learn to respect their own diversity as a group, while encouraging them to gradually overcome their learning difficulties.

It enables students to further explore the learning content that is most difficult to acquire; at the same time, it does not slow down the learning rhythm of one's fellow students, since the exploration of the subject matter takes place individually, outside the classroom. Moreover, it also helps to ensure that those who encounter the greatest difficulties don't feel left behind, since everyone has previously worked on the material before coming to class (FG-M, 2016/17).

Thanks to these experiences, students found that the learning experience had improved, and that the learning content was enriched both inside and outside the classroom. They also highlighted the fact that these Successful Educational Actions potentialize inclusivity and encourage students to help one another.

You learn from everyone, and they learn along with you. The knowledge possessed by the other students serves as an enriching source of expertise which we should not ignore. Collaboration among all helps us build greater knowledge and reinforce values that are needed in our society (FG-G, 2015/16).

Cooperative work results in a learning experience that goes far beyond what we find out by simply studying the subject matter. It helps develop other skills in us (FG-M, 2014/15).

Digital technology likewise ensures that a great deal of time is saved in classroom: instead of spending it on simple explanations, the implementation of these resources enable the students to explore more complex subject matter and embark on other kinds of projects that are more practical and relational. All of this becomes more flexible thanks to group and individual dynamics, as can be inferred from the following comment:

Digital technology leaves us more time in class to explore subject matter in depth instead of merely working on basic notions (FG-M, 2012/13).

Fluid, flexible class sessions, a positive atmosphere, and a heightened level of attendance were all aspects that were positively valued by university students. They pointed out that such an implementation of technology works in favor of ongoing training, and it also encourages teachers to get to know the students better, while in turn helping the students become more familiar with one another.

One student's closing remark on the importance of these actions in early teacher training shows what potential resources can unleash in favor of educational change: 
Schools should make a major change and adopt more modern teaching methods that encourage learning and are centered on the students' interests - without losing sight of the subject matter that needs to be imparted. In order to achieve this, the teacher should make use of a series of active and cooperative methodologies and of several analog and digital tools. The vision we acquired in these courses will help us bring about that change in schools (FG-G, 2018/19).

University students likewise positively valued the sequenced empowerment methodology featured in this project's assignments. They valued the introduction focused on sensitization to digital technology thanks to their experience in the role of teachers, the continual inclusion of novel pedagogical proposals in the course of the assignment, and the analysis of the use of technology from the perspective of their role as teachers, including potential variants of proposed activities according to which technology is used. This ultimately led them, in turn, to create their own activities that incorporated the use of digital resources. Students valued this sequenced experience positively for its transferability to the educational context where they will work in the future.

At university, I have had several professors who did not even allude once to technology. Others required that we include them in our term papers, but said "Just do it!" without indicating how; neither did they provide any example in their classes (FG-G, 2017/18)

In each academic year we found commentaries similar to the one above: students complained that in other courses they encountered the two extremes. Certain professors made no use of technology whatsoever, while others required their obligatory use without offering any sort of corresponding preparatory training.

\section{Discussion}

Our purpose in this study was to familiarize ourselves with the perception that university students of education (i.e., future primary and secondary school teachers) have of the integration of technology as they have experienced it in their general education and in their specifically musical training, along with the characteristics that exert an influence on the implementation of SEAs.

University students have reported information necessary to help us ascertain whether the social and technological development experienced over the last years is reflected, in parallel, in teaching and learning processes over which it inevitably exerts a fundamental, wide-ranging effect. We were particularly interested in the training of teachers within the context of Higher Education. Since the use of new forms of educational technology can either encourage or hamper the teaching-learning process, future teachers need to be equipped with the tools that enable them to tackle these challenges effectively. In order to succeed in this endeavor, they need to receive adequate training in the course of their university studies that they can transfer to the educational contexts in which they will work, and their professors not only need to be competent in the matter, but capable of pointing them in the right direction by helping them select the most adequate type of technology according to their specific needs (Bates \& Poole, 2003; Fallows \& Bhanot, 2005; Salinas et al., 2004). For students of education to receive quality university training in this field, their professors should propose a sequenced empowerment procedure that enables them to competently implement digital technology and leads them to develop constructivist teaching and learning, a sense of general efficacy, digital-related efficacy, and professional progress in the digital domain (Alt, 2018). In the area of digital teacher training, a truly pedagogical, reflective approach to content and activities is considered essential (Gall, 2017b; Mishra \& Koehler, 2006; Ping et al., 2018); however, initial training programs tend to scarcely or inadequately model the pedagogical use of technology (Martinovic \& Zhang, 2012). Four areas of competency have been found to have a direct influence on the quality of training offered by teacher educators: (1) technological competencies, (2) competencies in the pedagogical/educational use of technology, (3) beliefs about teaching/learning in relation with technology and ongoing training, and (4) competencies in the areas of innovation and professional learning (Uerz et al., 2018).

In line with the study conducted by Calderon-Garrido et al. (2021) on Spanish curricula, our results indicate that university teaching trainees have limited former experience with technology: this was revealed in their evaluation of the general educational level as well as of the specifically musical context, with the exception of the course in which a specific technological-methodological integration project was applied. Such minimal integration of technology was also patent in the results described by Sarramona (2004), who expressed the view that current technologies will only deliver a maximum educational yield when they come to form an integral, habitual part of the majority of school activities, and when teachers and students resort to them with the same comfort and assurance as they would exhibit when using a textbook or a blackboard.

These results are cause for particular concern: with each passing year, students are entering university training and are increasingly immersed in technological society; nevertheless, that immersion is by no means reflected in what they previously experienced in school (Domingo-Coscollola et al., 2020; Morales Capilla et al., 2015; Rodríguez Correa, 2018). Thus, in line with what is advocated by Taimalu and Luik (2019), initial teacher training needs to compensate for that deficit while placing a deliberate emphasis on an educational vein that integrates technology into pedagogy and curricular content. The latter authors underscore that university professors, in the assignments they teach, need to direct a greater amount of attention to technology's usefulness and the positive assessment thereof; they need to increase their 
technological proficiency and thereby transform their pedagogical proposals. This is especially important for teacher educators: consciously or unconsciously, they are serving as models for the students in their activities, preferences, and beliefs, thereby becoming "one of the key factors in the development of new teachers possessing a solid competency that enables them to integrate technology in their teaching activity" (p. 108).

In view of today's social and technological reality, teachers occasionally know less how to optimally apply technology in the classroom than their own students, as we pointed out in the previous section. This is in line with findings in the UK described by Savage $(2007,2010)$, who found that a significant portion of the teaching body admitted that their students knew more than they did about certain technological aspects. Our results are likewise in agreement with those obtained by Law and Chow (2008), who point out that the level of teacher proficiency in the use of technological resources is scant and low: teachers tend to be mere users of curricular material, rather than producers thereof.

Almerich et al. (2010) analyzed the relation between the integration of digital technology in the classroom and teachers' general familiarity with them; they found a significant relation between technological proficiency and pedagogical competence, similar to that ascertained in this study. Technological proficiency is a basis for pedagogical competence and facilitates it. In the results from that study, it is particularly remarkable to note that the teaching body exhibits a low level of proficiency regarding the integration of technological resources in the teaching-learning process (Almerich et al., 2010), although the use of digital resources has increased, particularly in the area of class preparation. Moreover, these authors point out that technological proficiency has a differential function that affects the integration of technology in the classroom: as a teacher becomes more familiar with technological resources, the integration thereof in teaching-learning processes likewise increases. They point out, however, that familiarity with digital technology is a necessary, yet not sufficient condition. Age and gender, attitudes toward technology, external motivation, and contextual viz. political-administrative elements are further important factors which likewise affect these processes (Almerich et al., 2010; Rodríguez Correa, 2018; Valverde \& Sosa, 2014).

Today, moreover, any institution associated with teaching/learning activities cannot achieve success without implementing processes that standardize educational quality. Quality is no longer an added value, but has become central in defining technical-pedagogical design and progression. In view of the importance of technology in helping to form this new society, it is likewise vital for education professionals to gain a grasp of the assumptions and guidelines involved in educational quality (Ehlers \& Pawlowski, 2006).

As we pointed out in previous sections, another focus of our study was the analysis of the methodology with which the educational activities with technology are carried out.
Just as previously pointed out by different authors (Area, 2007, 2019; Gall, 2017b; Mishra \& Koehler, 2006), teachers need to associate technology with changes in methodology that favor optimal learning in order to achieve musical digital SEAs.

As our participants indicated, the inclusion of technology on different educational levels had not brought about changes in methodology, but had merely perpetuated previous models still based on the passive role of the student. These results corroborated the theories of Almerich et al. (2010) and Morales Capilla et al. (2015), who found that teachers use digital resources more to support their own traditional methodology than as an element which could transform it. University musical courses in which a methodological-technological integration project was being implemented were the only ones which our participants associated with positive methodological changes.

Our participants' perception regarding benchmarks for the evaluation of SEAs with technology is in line with the arguments defended by Sosa Díaz et al. (2010) and Valverde and Sosa (2014), who highlighted aspects such as active, autonomous, and collaborative learning that promotes the development of cognitive abilities, creativity, and the broadening of knowledge, while respecting the diversity of the student body and encouraging students to overcome their learning difficulties. Canales and Marquès (2007) carried out an analysis of those factors which can work in favor of achieving SEAs related with technology, and they grouped the factors along several axes. One of the axes represents the relation between technology and learning, in which teachers need to potentialize their students' development of cognitive and metacognitive strategies, thereby stimulating the act of learning and the acquisition of digital knowledge and skills: positive socioaffective aspects are reinforced, just as we found in this study. Another axis represents the relation between the technology and the pedagogical task at hand: teachers should meticulously plan tasks and activities supported by technology in order ensure that the latter are adequately applied (Casanova \& Serrano, 2016; Román Álvarez, 2017); moreover, they should evaluate the technology-supported tasks and practical class assignments carried out by the students as well as their own educational practice. Opinions voiced by our participants regarding university musical courses point to aspects similar to those highlighted by Sosa Díaz et al. (2010) and Canales and Marquès (2007), Fallows and Bhanot (2005), Naidu (2003), and Salinas et al. (2004) thereby clearly justifying the consideration of musical activities involving digital resources as SEAs.

\section{Conclusions}

This study collects data obtained over the course of 7 years: opinions and perceptions voiced by students enrolled in a Spanish university regarding how they viewed the integration of technology in the musical classroom and the possibility of thereby achieving SEAs. After having analyzed their 
opinions, we conclude that generally in education and specifically in music education, students only had minimal previous experience with digital technology on different educational levels; moreover, the use of digital resources in the classroom had not been associated with a methodological transformation, but only tended to reinforce traditional methodologies while merely including some technology.

In all stages prior to the university music courses they attended, the students found that the frequency of use of technological tools and the quality of learning thereby achieved had been quite low, and varied widely from one institution to another as well as from one teacher to another. In the case of university music courses, however, the use of technology was quite positively evaluated: the activity was considered a SEA and highlighted as a model to be followed in the future. As Area $(2007,2019)$ has found, SEAs that incorporate digital technology involve a series of complex, multidimensional actions, including the representation, and understanding of concepts and procedures that help students obtain a grasp of subject matter via technology. As a precondition, however, constructivist didactic strategies using digital resources to convey subject matter need to be developed, since the presence of technology per se in the classroom does not automatically bring about an improvement in teaching and learning.

It is not only interesting but also necessary to familiarize ourselves with the difficulties that students encounter in their attempt to grasp subject matter, and to understand how technology can help them overcome such hindrances (Bates \& Poole, 2003). Another relevant aspect worthy of consideration is the students' previous knowledge and the epistemology of curriculum content in order to understand how digital technology can be applied in order to build new knowledge that grafts itself on to preceding knowledge, thereby generating new epistemologies (Valverde Berrocoso et al., 2010). Technology, in turn, is a powerful resource for the management, storage, and distribution of information, as well as for ensuring communication among human beings who are far removed from one another in terms of space or time (Area, 2007, 2019).

The usefulness of well-applied technological tools associated with a methodology that helps teachers carry out activities that are more dynamic and that enables them to host classes that are more practical and collaborative, and in which active student participation is potentialized - all of this is exactly what our participants were looking for. If one wants to effectively integrate a technology, a previous conceptualization needs to be formulated regarding the interaction between the technology, the curricular subject matter, and the pedagogical method (Koehler \& Mishra, 2008; Mishra \& Koehler, 2006; Román Álvarez, 2017). The didactic model adopted by the music specialist shall determine which musical content is featured, how it should be approached, the role played by professors and students in the process, and, consequently, the technological tools that are to be selected, as well as how they should be integrated into the educational process (Jorquera Jaramillo, 2010). Apart from technological proficiency, this study likewise confirms the importance of pedagogical knowledge that permits teachers to optimize these tools by applying active methodologies. As observed herein, it is of utmost importance to train future schoolteachers not only in technological skills, but also in pedagogical methodology (Aróstegui, 2010; Crawford, 2017; Domingo-Coscollola et al., 2020; Guerrero, 2014; Law \& Chow, 2008), thereby leading them to achieve SEAs that take the above-mentioned aspects into account.

Although it displays clear results, the present study has an evident limitation: the results cannot be generalized since this is a case study limited to students of the Education Faculty of the University of Zaragoza who participated in a technological-methodological integration project. The study would be more valuable if it had been complemented with quantitative information stemming from all project participants. This research was conducted prior to the pandemic situation of recent months. Undoubtedly, since then the use and management of technology has changed. It is desirable to continue analyzing, in the following courses, the use of technology to compare the situation pre and post COVID. We nevertheless believe that this study enriches the literature on the perceptions entertained by teaching trainees regarding the use of technology, thereby encouraging the implementation of a fundamental technological and methodological change in the use of technology in musical learning in Spain.

As a final conclusion, we find that further study and reflection should be devoted to the incorporation of digital technology in general teaching and in musical teaching: we should further analyze the use of digital resources, their usefulness, their advantages and difficulties, and learn to identify when they have been successfully applied in SEAs. In-depth analysis of experiences with technology in other locations, along with case studies of other university practices identifiable as SEAs will undoubtedly continue to nurture knowledge in this field. The optimal technological integration of digital resources in the first years of university training will certainly have beneficial repercussions on music teaching aimed at future generations on all educational levels.

\section{Acknowledgments}

The authors would like to acknowledge the University of Zaragoza (Spain) for the recognizing this project.

\section{Declaration of Conflicting Interests}

The author(s) declared no potential conflicts of interest with respect to the research, authorship, and/or publication of this article.

\section{Funding}

The author(s) received no financial support for the research, authorship, and/or publication of this article. 


\section{Ethic}

Ethical approval for this project was obtained from the University of Zaragoza in accordance with the requirements for this type of study. Participants were informed about the study's objective, and they signed a consent document. All participants were volunteers, and they were informed of their right to abandon the sessions at any moment they wished. We likewise requested their permission to make an audio recording of the group discussion while assuring them that their data would remain anonymous and confidential. Their personal identity was protected by omitting any detail that might have led to identification.

\section{ORCID iD}

Rosa M. Serrano (iD https://orcid.org/0000-0003-3704-3533

\section{References}

Adell, F. (2015). Digital natives: From the mith to reality. CCCBLAB. Investigació $i$ innovació en cultura. https://ab. cccb.org/en/digital-natives-from-the-myth-to-the-reality/

Almerich, G., Suárez, J. M., Orellana, N., \& Díaz, M. I. (2010). La relación entre la integración de las tecnologías de la información y comunicación y su conocimiento. Revista de Investigación Educativa, 18(1), 31-50.

Alonso-Ferreiro, A. (2018). Aprendizaje Basado en Proyectos para el desarrollo de la Competencia Digital Docente en la Formación Inicial del Profesorado. Revista Latinoamericana de Tecnología Educativa, 17(1), 9-24. https://doi.org/10. 17398/1695-288X.17.1.9

Alt, D. (2018). Science teachers' conceptions of teaching and learning, ICT efficacy, ICT professional development and ICT practices enacted in their classrooms. Teaching and Teacher Education, 73, 141-150. https://doi.org/10.1016/j. tate.2018.03.020

Area, M. (2007). Algunos principios para el desarrollo de buenas prácticas pedagógicas con las TICs en el aula. Comunicación y Pedagogía: Nuevas Tecnologías y Recursos Didácticos, 222, 42-47.

Area, M. (2019). Reinventing schools and the educational materials in the digital society. In J. Rodríguez, T. Braga, \& E. Bruillard (Eds.), IARTEM 1991-2016. 25 years developing textbook and educational media research (pp. 371-376). Andavira.

Aróstegui, J. L. (2005). Las Tecnologías de la Información y la Comunicación en el aula de música. Musiker, 14, 173-189. https://core.ac.uk/download/pdf/11502427.pdf

Aróstegui, J. L. (2010). Risks and promises of ICT for music education. Hellenic journal of music. Education and Culture, 1, 17-31. http://hejmec.eu/journal/index.php/HeJMEC/article/ view/19

Balanskat, A., Blamire, R., \& Kefala, S. (2006). The ICT impact report: A review of studies of ICT impact on schools in Europe. European Schoolnet. http://www.esode.com/downloadable\%20 files/OTHER\%20DOCUMENTS/impact_study.pdf

Bates, A. W., \& Poole, G. (2003). Effective teaching with technology in higher education: Foundations for success. Jossey-Bass.

Bauer, W. I. (2013). The acquisition of musical technological pedagogical and content knowledge. Journal of Music Teacher Education, 22(2), 51-64. https://doi.org/10.1177/ 1057083712457881
Bauer, W. I. (2014). Music learning today: Digital pedagogy for creating, performing, and responding to music. Oxford University Press.

Bautista, A. (Coord.) (2004). Las nuevas tecnologías en la enseñanza: temas para el usuario. Akal.

Blaxter, L., Hughes, C., \& Tight, M. (2008). Cómo se investiga. Graó.

Bourke, B., \& State, M. (2019). Connecting with generation $\mathrm{Z}$ through social media. In H. Lee \& C. Johnson (Eds.), Preparing the higher education space for Gen Z (pp. 124-147). IGI Global.

Bringué, X., \& Sádaba, C. (2009). La Generación Interactiva en España. Niños y adolescentes ante las pantallas. Ariel.

Byrne, C., \& MacDonald, R. A. R. (2002). The use of Information \& communication technology (I\&CT) in the Scottish music curriculum: A focus group investigation of themes and issues. Music Education Research, 4(2), 263-273. https://doi. org/10.1080/1461380022000011957

Calderon-Garrido, D., Carrera, X., \& Gustems-Carnicer, J. (2021). La presencia de las TIC en las asignaturas de música de los Grados de Maestro. Revista Electrónica Complutense de Investigación en Educación Musical - RECIEM, 18, 127-138. https://doi.org/10.5209/reciem.64882

Calderón-Garrido, D., Cisneros, P., García, I. D., Fernández, D., \& De Las Heras, R. (2019). La tecnología digital en la educación musical: una revisión de la literatura científica. Revista Electrónica Complutense de Investigación en Educación Musical - RECIEM, 16, 43-55. https://doi.org/10.5209/ reciem. 60768

Calderón-Garrido, D., Gustems-Carnicer, J., \& Carrera, X. (2020). Digital technologies in music subjects on primary teacher training degrees in Spain: Teachers' habits and profiles. International Journal of Music Education, 38(4), 613-624. https://doi.org/10.1177/0255761420954303

Canales, R., \& Marquès, P. (2007). Factores de buenas prácticas educativas con apoyo de las TIC. Análisis de su presencia en tres centros educativos. Educar, 39, 115-133.

Casanova, O., \& Serrano, R. M. (2016). Internet, tecnología y aplicaciones para la educación musical universitaria del siglo XXI. REDU. Revista de Docencia Universitaria, 14, 405-421. https://doi.org/10.4995/redu.2016.5801

Chen, F., Gorbunova, N. V., Masalimova, A. R., \& Bírová, J. (2017). Formation of ICT-competence of future university school teachers. Eurasia Journal of Mathematics Science and Technology Education, 13(8), 4765-4777. https://doi. org/10.12973/eurasia.2017.00963a

Colás, M. P., De-Pablos, J., \& Ballesta, J. (2018). Incidencia de las TIC en la enseñanza en el sistema educativo español: una revisión de la investigación. Revista de Educación a Distancia (RED), 18(56), 1-23. https://doi.org/10.6018/red/56/2

Coll, C., Mauri, T., \& Onrubia, J. (2008). Análisis de los usos reales de las TIC en contextos educativos formales: Una aproximación socio-cultural. Revista Electrónica de Investigación Educativa, 10(1), 1-18. https://redie.uabc.mx/redie/article/view/177

Cózar Gutiérrez, R., De Moya Martínez, M. D. V., Hernández Bravo, J. A., \& Hernández Bravo, J. R. (2015). TIC, estilos de aprendizaje y competencia musical en los estudios de grado de Maestro. Revista Electrónica Complutense de Investigación en Educación Musical - RECIEM, 12, 73-85. https://doi. org/10.5209/rev_reciem.2015.v12.47752 
Crawford, R. (2017). Rethinking teaching and learning pedagogy for education in the twenty-first century: Blended learning in music education. Music Education Research, 19(2), 195-213. https://doi.org/10.1080/14613808.2016.1202223

De Castro, C. (2015). Recursos educativos TIC en la enseñanza musical pianística. Revista Electrónica Complutense de Investigación en Educación Musical - RECIEM, 12, 37-52. https://doi.org/10.5209/rev_reciem.2015.v12.49004

Denzin, N. K., \& Lincoln, Y. S. (2005). The Sage Handbook of qualitative research. SAGE.

De Pablos, J., \& Jiménez, R. (2007). Buenas prácticas con TIC apoyadas en las Políticas Educativas: claves conceptuales y derivaciones para la formación en competencias ECTS. Revista Latinoamericana de Tecnología Educativa, 6(2), 15-28.

Domingo-Coscollola, M., Bosco-Paniagua, A., Carrasco-Segovia, S., \& Sánchez-Valero, J. A. (2020). Fomentando la competencia digital docente en la universidad: Percepción de estudiantes y docentes. Revista de Investigación Educativa, 38(1), 167-782. https://doi.org/10.6018/rie.340551

Dorfman, J. (2013). Theory and practice of technology-based music instruction. Oxford University Press.

Dorfman, J. (2015). Perceived importance of technology skills and conceptual understandings for pre-service, early-career, and late-career music teachers. College Music Symposium, 55. http://bit.ly/1FswGr9

Dorfman, J. (2016). Music teachers' experiences in one-to-one computing environments. Journal of Research in Music Education, 64(2), 159-178. https://doi.org/10.1177/00224 29416649947

Eatough, V., \& Smith, J. A. (2017). Interpretative phenomenological analysis. In C. Willig \& W. Stainton-Rogers (Eds.), Handbook of qualitative psychology (2nd ed., pp. 193-211). SAGE.

Ehlers, U. D., \& Pawlowski, J. M. (Eds.). (2006). Handbook on quality and standardisation in E-learning. Springer.

Enochsson, A., \& Rizza, C. (2009). ICT in initial teacher training: Research review. OECD Education Working Papers, 38, 1-41. https://doi.org/10.1787/220502872611

Epper, R. M., \& Bates, A. W. (2004). Enseñar al profesorado cómo utilizar la tecnología. Buenas prácticas de instituciones líderes. UOC.

Fallows, S., \& Bhanot, R. (Eds.). (2005). Quality issues in ICTbased higher education. Routledge.

Flick, U. (2014). La gestión de la calidad en Investigación Cualitativa. Morata.

Flick, U. (2015). El diseño de Investigación Cualitativa. Morata.

Gabarda Méndez, V. (2015). Uso de las TIC en el profesorado europeo: ¿Una cuestión de equipamiento y formación? Revista Española de Educación Comparada, 0, 153-170. https://doi. org/10.5944/reec.26.2015.14448

Gallego Arrufat, M. J., Gámiz Sánchez, V., \& Gutiérrez Santiuste, E. (2010). El futuro docente ante las competencias en el uso de las tecnologías de la información y comunicación para enseñar. EDUTEC. Revista Electrónica de Tecnología Educativa, 34, a144. https://doi.org/10.21556/edutec.2010.34.418

Gall, M. (2017a). Technology in music initial teacher education. In S. A. Ruthmann \& R. Mantie (Eds.), The Oxford Handbook of Technology and music education (pp. 688-695). Oxford University Press.
Gall, M. (2017b). TPACK and music teacher education. In A. King, E. Himonides, \& S. A. Ruthmann (Eds.), The Routledge companion to technology and music education (pp. 305-318). Routledge.

Gibbs, G. (2012). El análisis de datos cualitativos en Investigación Cualitativa. Morata.

Giráldez, A. (2005). Internet y educación musical. Graó.

Giráldez, A. (2010). Repensar la educación musical en un mundo digital. In A. Giráldez (Ed.), Música. Complementos de formación disciplinar (pp. 73-100). Graó.

Gómez, J. (Ed.). (2016). UNIVERSITIC 2016. Análisis de las TIC en las Universidades Españolas. Crue Universidades Españolas. https://tic.crue.org/wp-content/uploads/2017/04/ UNIVERSITIC-2016-con-portadas.pdf

Green, L. (2016). Music education as critical theory and practice. Selected essays. Routledge.

Gudmundsdottir, G. B., \& Hatlevik, O. E. (2018). Newly qualified teachers' professional digital competence: Implications for teacher education. European Journal of Teacher Education, 41(2), 214-231. https://doi.org/10.1080/02619768.2017.141 6085

Guerrero, J. L. (2014). Evaluando actitudes y usos de las TIC del profesorado de música de educación secundaria. RIEM. Revista Internacional de Educación Musical, 2, 10-23. https:// doi.org/10.12967/riem-2014-2-p010-023

Instefjord, E., \& Munthe, E. (2016). Preparing pre-service teachers to integrate technology: An analysis of the emphasis on digital competence in teacher education curricula. European Journal of Teacher Education, 39(1), 77-93. https://doi.org/10.1080/0 2619768.2015.1100602

Jorquera Jaramillo, M. C. (2010). Modelos didácticos en la enseñanza musical: el caso de la escuela española. Revista musical chilena, 64(214), 52-74.

Juvonen, A., \& Ruismäki, H. (2009). The new horizons for music technology in music education [Oral Communication]. Second international conference the changing face of music education / CFME09 - Music and Environment, Tallinn, Estonia. http:// www.tlu.ee/CFMAE/CFME09_Juvonen_Ruismaki.pdf

Kallio, K. P., Kaipainem, K., \& Mäyrä, F. (2007). Gaming nation? Piloting the international study of games cultures in Finland. Hypermedia Laboratory - University of Tampere. https://repo. tuni.fi/handle/10024/65774

Kirschner, P. A., \& De Bruyckere, P. (2017). The myths of the digital native and the multitasker. Teaching and Teacher Education, 67, 135-142. https://doi.org/10.1016/j.tate.2017.06.001

Koehler, M. J., \& Mishra, P. (2008). Introducing TPCK. In AACTE Committee on Innovation and Technology (Eds.), The handbook of technological pedagogical content knowledge (TPCK) for educators (pp. 3-29). Routledge.

Kvale, S. (2011). Las entrevistas en Investigación Cualitativa. Morata.

Law, N., \& Chow, A. (2008). Teacher characteristics, contextual factors, and how these affect the pedagogical use of ICT. In N. Law, W. Pelgrum, \& T. Plomp (Eds.), Pedagogy and ICT use in schools around the world (pp. 181-219). Springer.

Losada, D., Valverde, J., \& Correa, J. M. (2012). La tecnología educativa en la universidad pública española. Píxel-Bit. Revista de Medios y Educación, 41, 133-148. https://recyt.fecyt.es/index. $\mathrm{php} / \mathrm{pixel} / \mathrm{article} / \mathrm{view} / 61595$ 
Martinovic, D., \& Zhang, Z. (2012). Situating ICT in the teacher education program: Overcoming challenges, fulfilling expectations. Teaching and Teacher Education, 28, 461-469. https:// doi.org/10.1016/j.tate.2011.12.001

Miles, M. B., Huberman, A. M., \& Saldaña, J. (2013). Qualitative data analysis: A methods sourcebook. SAGE.

Mishra, P., \& Koehler, M. J. (2006). Technological pedagogical content knowledge: A framework for teacher knowledge. Teachers College Record, 108(6), 1017-1054.

Montoya, J. C. (2013). Educación musical renovada: una película por filmar. Eufonía, 57, 91-98.

Morales Capilla, M., Trujillo Torres, J. M., \& Raso Sánchez, F. (2015). Percepciones acerca de la integración de las TIC en El proceso de enseñanza-aprendizaje de la Universidad. PíxelBit. Revista de Medios y Educación, 46, 103-117. https://doi. org/10.12795/pixelbit.2015.146.07

Moustakas, C. E. (1994). Phenomenological research methods. SAGE.

Naidu, S. (Ed.). (2003). Learning and teaching with technology: Principles and practices. Routledge.

National Institute of Statistics. (2020). Encuesta sobre equipamiento y uso de Tecnologías de Información y Comunicación en los hogares. INE. https://www.ine.es/prensa/tich_2020.pdf

Palmer, M., Larkin, M., de Visser, R., \& Fadden, G. (2010). Developing an interpretative phenomenological approach to focus group data. Qualitative Research in Psychology, 7(2), 99-121. https://doi.org/10.1080/14780880802513194

Pike, P. D. (2017). Improving music teaching and learning through online service: A case study of a synchronous online teaching internship. International Journal of Music Education, 35(1), 107-117. https://doi.org/10.1177/0255761415613534

Ping, C., Schellings, G., \& Beijaard, D. (2018). Teacher educators' professional learning: A literature review. Teaching and Teacher Education, 75, 93-104. https://doi.org/10.1016/j. tate.2018.06.003

Prendes, M. P., Gutiérrez, I., \& Martínez, F. (2018). Competencia digital: una necesidad del profesorado universitario en el siglo XXI. RED. Revista de Educación a Distancia, 18(56), 1-22. https://doi.org/10.6018/red/56/7

Pritchard, A., \& Woollard, J. (2010). Psychology for the classroom: Constructivism and social learning. Routledge.

Rodríguez Correa, M. (2018). La integración de las TIC en los centros universitarios: la visión de los directivos. EDUTEC. Revista Electrónica de Tecnología Educativa, 64, 41-50. https://doi.org/10.21556/edutec.2018.64.975

Rodríguez Pérez, I. (2015). La importancia de las competencias digitales de los docentes, en la sociedad del conocimiento. Revista Iberoamericana de Producción Académica y Gestión Educativa, 2(3), 1-12. https://www.pag.org.mx/index.php/ PAG/article/view/484

Román Álvarez, M. (2017). Tecnología al servicio de la educación musical. Revista Española de Pedagogía, 75(268), 481-495. https://doi.org/10.22550/rep75-3-2017-09

Salinas, J., Aguaded, J. I., \& Cabero, J. (Coord.) (2004). Tecnologías para la educación. Diseño, producción y evaluación de medios para la formación docente. Alianza.

Sarramona, J. (2004). Factores e indicadores de calidad en la educación. Octaedro.

Savage, J. (2007). Reconstructing music education through ICT. Research in Education, 78, 65-77.
Savage, J. (2010). A survey of ICT usage across English secondary schools. Music Education Research, 12(1), 89-104. https://doi. org/10.1080/14613800903568288

Sefo, K., Granados Romero, J. M., Lázaro, M. N., \& FernándezLarragueta, S. (2017). La formación del profesorado para un uso innovador de las TIC: un estudio de caso en la educación obligatoria en la provincia de Almería. Profesorado. Revista de Currículum y Formación de Profesorado, 21(4), 241-258. http://www.redalyc.org/articulo.oa?id=56754639013

Serrano, R. M. (2017). Tecnología y educación musical obligatoria en España: Referentes para la implementación de buenas prácticas. RECIEM. Revista Electrónica Complutense de Investigación en Educación Musical, 14, 153-169. https://doi. org/10.5209/RECIEM.54848

Sloep, P., \& Berlanga, A. (2011). Learning networks, networked learning. Comunicar, 37, 55-64. https://doi.org/10.3916/C372011-02-05

Smith, J. A., Flowers, P., \& Larkin, M. (2009). Interpretative phenomenological analysis: Theory, method and research. SAGE.

Smith, J. A., \& Osborn, M. (2015). Interpretative phenomenological analysis. In J. A. Smith (Ed.), Qualitative psychology: A practical guide to research methods (pp. 25-52). SAGE.

Sosa Díaz, M. J., Peligros García, S., \& Díaz Muriel, D. (2010). Buenas prácticas organizativas para la integración de las TIC en el sistema educativo extremeño. Revista Electrónica Teoría de la Educación. Educación y Cultura en la Sociedad de la Información, 11(1), 148-179.

Strauss, A., \& Corbin, J. (2002). Bases de la investigación cualitativa. Técnicas y procedimientos para desarrollar la teoría fundamentada. Editorial Universidad de Antioquia.

Sweeney, T., West, D., Groessler, A., Haynie, A., Higgs, B. M., Macaulay, J., Mercer-Mapstone, L., \& Yeo, M. (2017). Where's the transformation? Unlocking the potential of technology-enhanced assessment. Teaching \& Learning Inquiry, 5(1), 1-13. https://doi.org/10.20343/5.1.5

Taimalu, M., \& Luik, P. (2019). The impact of beliefs and knowledge on the integration of technology among teacher educators: A path analysis. Teaching and Teacher Education, 79, 101-110. https://doi.org/10.1016/j.tate.2018.12.012

Talsik, E. (2015). The investigation of readiness for e-learning of preservice music teachers in Turkey. The Anthropologist, 21(1-2), 263-270. https://doi.org/10.1080/09720073.2015.11891815

Tapia Cortes, C. (2020). Tipologías de uso educativo de las Tecnologías de la Información y Comunicación: una revisión sistemática de la literatura. EDUTEC. Revista Electrónica de Tecnología Educativa, 71, 16-34. https://doi.org/10.21556/ edutec.2020.71.1489

Tomczyk, Ł., \& Oyelere, S. S. (2019). ICT for learning and inclusion in Latin America and Europe. Pedagogical University of Cracow. https://doi.org/10.24917/9788395373732

Tomkins, L., \& Eatough, V. (2010). Reflecting on the use of IPA with focus groups: Pitfalls and potentials. Qualitative Research in Psychology, 7(3), 244-262. https://doi.org/10. 1080/14780880903121491

Torres, L. (2011). Aplicación de las TIC en el aula de educación musical de la educación primaria. Musytic.com, un recurso para el docente. Eufonía, 52, 63-70.

Uerz, D., Volman, M., \& Kral, M. (2018). Teacher educators' competences in fostering student teachers' proficiency in teaching and learning with technology: An overview of relevant research 
literature. Teaching and Teacher Education, 70, 12-23. https:// doi.org/10.1016/j.tate.2017.11.005

Valverde Berrocoso, J., Garrido Arroyo, M. D. C., \& Fernández Sánchez, R. (2010). Enseñar y aprender con tecnologías: un modelo teórico para las buenas prácticas educativas con TIC. Revista Electrónica Teoría de la Educación. Educación y Cultura en la Sociedad de la Información, 11(1), 203-229.

Valverde, J., \& Sosa, M. J. (2014). Centros educativos e-competentes en el modelo 1:1. El papel del equipo directivo, la coordinación TIC y el clima organizativo. Profesorado. Revista de Currículum y Formación de Profesorado, 18(3), 41-62.

van de Oudeweetering, K., \& Voogt, J. (2018). Teachers' conceptualization and enactment of twenty-first century competences: Exploring dimensions for new curricula. The Curriculum Journal, 29(1), 116-133. https://doi.org/10.1080/09585176.2017.1369136 van Laar, E., van Deursen, A. J. A., van Dijk, J. A. G., \& de Haan, J. (2017). The relation between 21st-century skills and digital skills: A systematic literature review. Computers in Human Behavior, 72, 577-588. https://doi.org/10.1016/j. chb.2017.03.010

van Laar, E., van Deursen, A. J. A. M., van Dijk, J. A. G. M., \& de Haan, J. (2020). Determinants of 21st-century skills and 21st-century digital skills for workers: A systematic literature review. Sage Open, 10, 1-14. https://doi.org/10.1177/ 2158244019900176

Vidulin-Orbanić, S., \& Duraković, L. (2011). The influence of educational technology on the development of music students' competences. Croatian Journal of Education, 13(2), 124-160. https://hrcak.srce.hr/76348

Webster, P. R. (2002). Computer-based technology and music teaching and learning. In R. Colwell \& C. Richardson (Eds.), The new handbook of research on music teaching and learning. A project of the music educators national conference (pp. 416-442). Oxford University Press. 